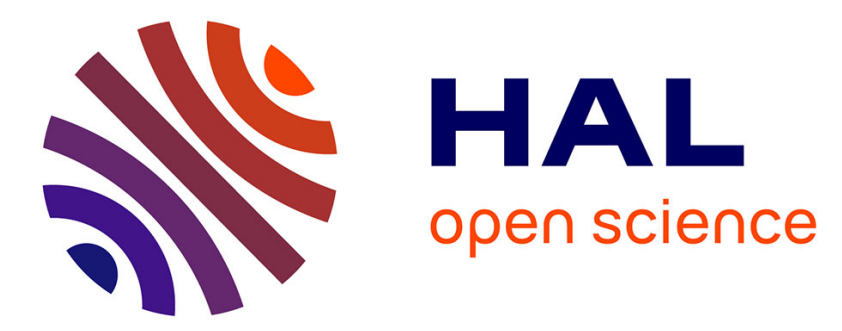

\title{
Preservation of bone collagen sulphur isotopic compositions in an early Holocene river-bank archaeological site
}

Hervé Bocherens, Dorothée G. Drucker, Heinrich Taubald

\section{- To cite this version:}

Hervé Bocherens, Dorothée G. Drucker, Heinrich Taubald. Preservation of bone collagen sulphur isotopic compositions in an early Holocene river-bank archaeological site. Palaeogeography, Palaeoclimatology, Palaeoecology, 2011, 310 (1-2), pp.32 - 38. 10.1016/j.palaeo.2011.05.016 . hal-01381856

\section{HAL Id: hal-01381856 \\ https://hal.science/hal-01381856}

Submitted on 14 Oct 2016

HAL is a multi-disciplinary open access archive for the deposit and dissemination of scientific research documents, whether they are published or not. The documents may come from teaching and research institutions in France or abroad, or from public or private research centers.
L'archive ouverte pluridisciplinaire HAL, est destinée au dépôt et à la diffusion de documents scientifiques de niveau recherche, publiés ou non, émanant des établissements d'enseignement et de recherche français ou étrangers, des laboratoires publics ou privés.

\section{(c)(1)}

Distributed under a Creative Commons Attribution| 4.0 International License 


\title{
Preservation of bone collagen sulphur isotopic compositions in an early Holocene river-bank archaeological site
}

\author{
Hervé Bocherens ${ }^{\mathrm{a}, *}$, Dorothée G. Drucker ${ }^{\mathrm{a}, \mathrm{b}}$, Heinrich Taubald ${ }^{\mathrm{c}}$ \\ ${ }^{a}$ Fachbereich Geowissenschaften, Paläobiologie (Biogeologie), Universität Tübingen, Hölderlinstraße 12, 72074 Tübingen,Germany \\ ${ }^{\mathrm{b}}$ Institut für Ur- und Frühgeschichte, Naturwissenschaftliche Archäologie, Universität Tübingen, Rümelinstraße 23, 72070 Tübingen,Germany \\ c Fachbereich Geowissenschaften, AB Mineralogie und Geodynamik, Universität Tübingen, Wilhelmstraße 56, 72074 Tübingen,Germany
}

\begin{abstract}
This study investigates the reliability of the sulphur isotopic compositions $\left(\delta^{34} \mathrm{~S}\right)$ of collagen in archaeological bones from an early Holocene river-bank site, Noyen-sur-Seine (France). The chemical composition (C, N, S) of whole bones compared to those of bones from cave sites suggests that contamination with sulphur is higher in the bones sampled from river bank deposits compared to those from caves, especially those that occur well above the water table. Sulphur content in fresh bone collagen suggests specific values for different mammal taxa, while sulphur content in reptile bones may not always be higher than those of mammals. In the early Holocene bones from Noyen-sur-Seine, the collagen has chemical characteristics within the overall range observed in modern bone collagen. However, co-variation between some diagenetic indicators, such as sulphur content and N/S in whole bone, \%S in collagen, and S yield, and $\delta^{34} \mathrm{~S}$ values of collagen from the same species or ecological groups indicate that some diagenetic alteration may have influenced the collagen. Excluding samples possibly affected by this alteration, a difference in $\delta^{34} \mathrm{~S}$ is measured between freshwater and terrestrial fauna. We recommend further work on the collagen sulphur contents in different species. Moreover, whole bone chemical compositions may help to screen samples for sulphur isotopic analyses of collagen that are to be used for palaeodietary reconstructions.
\end{abstract}

\section{Introduction}

Sulphur isotope compositions of collagen are increasingly used to investigate palaeodiets (e.g. Leach et al., 1996; Richards et al., 2001, 2003; Craig et al., 2006, 2010; Privat et al., 2007; Athfield et al., 2008; Nehlich et al., 2010). This isotopic tracer is particularly useful in the distinction of terrestrial and freshwater food resources (Nehlich et al., 2010). Indeed, carbon and nitrogen stable isotope compositions, the most widely used isotopic tracers of palaeodiets, are sometimes ambiguous to quantify the respective contribution of terrestrial and freshwater foods, as isotopic ratios of carbon vary in a similar range in these two resources (e.g., Dufour et al., 1999), while nitrogen isotopic abundances may vary spatially and chronologically in terrestrial plants and herbivores (e.g. Bocherens et al., 2000a; Drucker et al., 2003; Drucker and Bocherens, 2004). The composition of sulphur isotopes in food webs depends on the characteristics of the geological bedrock and on the microbial processes involved in the biogeochemical cycle of sulphur, which may lead to differences in the isotopic compositions of freshwater and terrestrial food webs in a given locality (e.g. Krouse, 1989). Therefore, it is predicted that in most contexts, it will be possible to measure isotopic differences between terrestrial and freshwater food resources, a prediction confirmed in the case of the Danube Gorges in Serbia and Romania (Nehlich et al., 2010), although sometimes more complex situations occur (e.g. Privat et al., 2007).

In any case, detecting and quantifying freshwater food resources in ancient human diets is not only important to reconstruct the evolution of subsistence strategies, but it is also essential to correct radiocarbon dates from possible reservoir effect that will yield excessively old dates if not taken into account (e.g. Cook et al., 2001; Bocherens, 2009; Olsen et al., 2010). The issue of freshwater food consumption is especially relevant in the case of archaeological sites located near rivers or lakes. However, in such taphonomic contexts, bones are often contaminated by exogenous organic matter (e.g. Bocherens et al., 1997a) and such contamination may introduce high amounts of exogenous sulphur that could interfere with the use of sulphur isotope compositions as a tracer for the source of sulphur in archeaological bones as collagen sulphur content is very low (Richards et al., 2001). Therefore, it seems essential to test the specific case of archaeological sites close to water bodies for possible diagenetic alteration of sulphur isotopic abundances of bones.

The present study focuses on the possible alteration of sulphur isotopic compositions of bone collagen in one surficial, archaeological 
site within peat levels located on a river bank (Noyen-sur-Seine). We measured the whole bone chemical composition in nitrogen and sulphur in this site to evaluate collagen loss and sulphur contamination. Similar measurements were made in modern bones and bones sampled from caves (Kesslerloch and Hohle Fels) where the input of exogenous organic matter was likely more limited, since no such data are known to exist so far. We considered the reliability of the collagen from Noyen-sur-Seine bones using the general rules established by Nehlich and Richards (2009). Furthermore, we investigated possible additional criteria for the reliability of the sulphur isotopic analysis in this case.

\section{Material}

A set of modern mammal bones was used as reference dataset for sulphur content in whole fresh bone (Table 1 in supplementary data). Collagen extracted from 23 fresh bones from various species of mammals (brown bear Ursus arctos, polar bear Ursus maritimus, caribou Rangifer tarandus, and camel Camelus dromedarius) and one reptile (Greek turtle Testudo graeca) was used to establish the range of chemical compositions of collagen, especially those of sulphur (Table 2 in supplementary data). These data were used to compare the chemical characteristics of collagen from modern bones with those obtained by Nehlich and Richards (2009) on a larger dataset.

Bones from three archaeological sites were investigated for sulphur contamination in bones (Fig. 1): Hohle Fels (BadenWürttemberg, Germany), Kesslerloch (Schaffhausen, Switzerland) and Noyen-sur-Seine (Seine-et-Marne, France). These sites provide good examples of contrasted taphonomic contexts. Bones from Noyen-sur-Seine were further tested for possible alteration of sulphur isotopic compositions of collagen.

The Hohle Fels cave is a large cave formed within the Upper Jurassic limestone and situated on the eastern extension of the Swabian Jura about $20 \mathrm{~km}$ west of Ulm (Baden-Württemberg, Germany). The cave is located $534 \mathrm{~m}$ asl in the valley of the Ach River, a tributary of the Danube, and $7 \mathrm{~m}$ above the current valley bottom (Schiegl et al., 2003). This site has yielded thousands of large mammal bones ranging in age from around 13,000 to around 35,000 years ago (Münzel et al., 2008). The material investigated in the present study consists essentially of cave bear Ursus spelaeus and brown bear Ursus arctos bones, with a few cave lion Panthera spelaea and horse Equus ferus bones (Bocherens et al., in press).

The Kesslerloch site is located in the Canton of Schaffhausen at Thayngen in Switzerland near the German border (Merk, 1876; Napierala, 2008). The cave is dug into upper Jurassic limestone and its

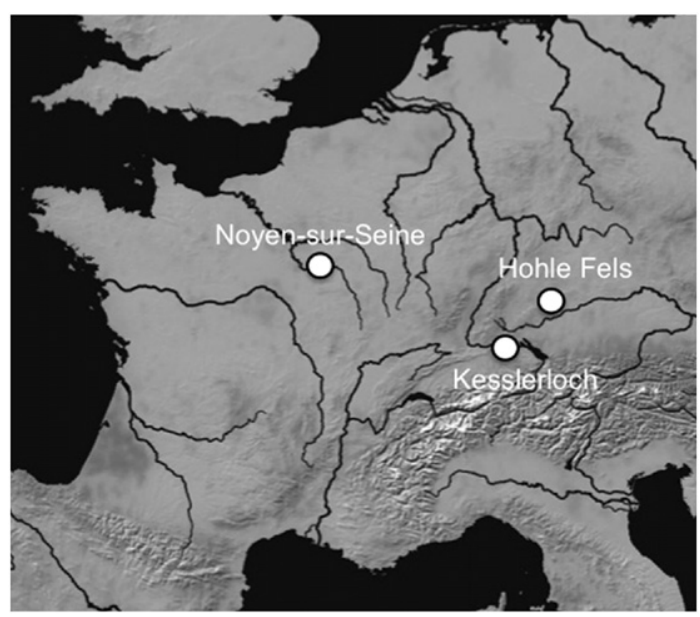

Fig. 1. Location map of the three archaeological sites discussed in the text: Noyen-surSeine (France), Kesslerloch (Switzerland) and Hohle Fels (Germany). entrance lies at the level of the valley. The studied fauna ranges in age from 15,000 to $11,000 \mathrm{BP}$. The studied bones belong to a variety of species, including horse Equus ferus, mammoth Mammuthus primigenius, woolly rhinoceros Coelodonta antiquitatis, cave lion Panthera spelaea, bison Bison sp, wolf Canis lupus, wolverine Gulo gulo, fox Vulpes vulpes, lynx Lynx lynx, hare Lepus timidus and ground squirrel Spermophilus rufescens (Bocherens et al., in press).

Noyen-sur-Seine is located in an early Holocene fossil channel of the Seine river between Nogent-sur-Seine and Hogereau (Seine-etMarne, France). This open-air site with peat levels yielded not only well-preserved bones, but also vegetal artefacts such as a monoxyl boat and fishing nets. The main occupation was during the late Boreal, around 8000 years BP, and corresponds to the Mesolithic culture (Marinval-Vigne et al., 1989). The studied fauna includes terrestrial animals such as red deer Cervus elaphus, roe deer Capreolus capreolus, aurochs Bos primigenius, wild boar Sus scrofa, wolf Canis lupus, fox Vulpes vulpes, lynx Lynx lynx, as well as freshwater dwellers such as otter Lutra lutra and European pond turtle Emys orbicularis. This last species was included as its bones bear numerous cut marks and burning traces that testify that European pond turtles were consumed by humans in this site (Marinval-Vigne et al., 1989). This species is also abundantly represented in European Holocene sites close to water bodies and was consumed by prehistoric people (e.g., Lehmkuhl, 1989; Cheylan, 1998; Gramsch and Larsson, 2001; Kerkesz, 2002; Lillie et al., 2003; Bösl et al., 2006; Sommer et al., 2007; Chiquet and Chaix, 2009). The carbon and nitrogen isotopic compositions of collagen from the material from Noyen-sur-Seine were previously presented (Bocherens et al., 2000b).

\section{Methods}

Bones from the three archaeological sites were sampled for determination of nitrogen $(\% \mathrm{~N})$ and sulphur content $(\% \mathrm{~S})$ in whole bones to decipher taphonomic effects, while bone collagen chemical and isotopic composition at Noyen-sur-Seine were also analysed to address the reliability of sulphur isotopic compositions of ancient collagen.

The following proxies for intensity of diagenetic alteration of bone were defined using whole bone elemental analysis: decreasing \% $\mathrm{N}$ corresponds to increasing loss of collagen (Iacumin et al., 1996; Bocherens et al., 1997b, 2005, 2008) while increasing \%S in bone reflects increasing exogenous sulphur-bearing contamination. In order to take into account the level of remaining collagen and of sulphur contamination in bone, we used the N/S ratio in whole bone, a ratio that will decrease when collagen amount remaining in bone decreases and exogenous sulphur increases.

In addition, the chemical composition of ancient collagen was compared to that of fresh collagen. The reliability of collagen sulphur isotopic compositions was investigated by examining possible covariations between the isotopic compositions within given species or ecological groups and the indicators of diagenetic intensity, i.e. changes in chemical composition of bone and collagen.

Sample preparation was performed as follows. Small pieces of bone were cut from identified remains, sonicated in acetone and then rinsed three times in distilled water. After crushing and sieving to obtain a powder of $0.7 \mathrm{~mm}$ grain size, an aliquot of around $5 \mathrm{mg}$ was used to measure the elemental composition ( $, \mathrm{N}, \mathrm{S}$ ) of the whole bone, using an approach modified from Bocherens et al. (2005). The measurements were performed using a Vario EL III elemental analyser using Sulfanilic acid from Merck as internal standard. The mean standard errors were better than of $0.02 \%, 0.05 \%$, and $0.03 \%$ for $\%$, $\% \mathrm{~N}$ and $\% \mathrm{~S}$, respectively.

Collagen extraction was performed following a modified Longin method (Longin, 1971; Bocherens et al., 1997b). The elemental ratios C/ $\mathrm{S}$ and $\mathrm{N} / \mathrm{S}$ were calculated as atomic ratios. The S-isotopic composition was measured with an NC 2500 elemental analyser connected to a 
Thermo-Quest Delta + XL mass spectrometer. Samples were calibrated to $\delta^{34} S$ values relative to CDT of NBS $123\left(\delta^{34} S=17.10 \%\right)$, NBS 127 $\left(\delta^{34} S=20.31 \%\right)$, IAEA-S-1 $\left(\delta^{34} S=-0.30 \%\right)$ and IAEA-S-3 $\left(\delta^{34} \mathrm{~S}=21.70 \%\right.$ ). The reproducibility is $\pm 0.4 \%$ for $\delta^{34} \mathrm{~S}$ measurements, and the error on amount of S measurement is $5 \%$.

\section{Results}

\subsection{Chemical composition of bone}

Sulphur amounts ranged from 0.08 to $0.30 \% \mathrm{~S}$ in modern bones (Table 1 and Table 1 in supplementary data). The archaeological bones from the three archaeological sites differed in the amount of sulphur that they contained (Table 1; Fig. 2). The bones from Hohle Fels did not contain more sulphur than the modern bones studied here. In contrast, the mammal bones from Noyen-sur-Seine exhibited higher amounts of sulphur than fresh bones, which corresponds to contaminating sulphur. The bones from Kesslerloch contained less sulphur than those from Noyen-sur-Seine, but more sulphur than those from Hohle Fels and than modern bones. The level of sulphur contamination was not correlated with the amount of collagen loss, neither globally, nor in individual sites (Fig. 2).

The N/S ratios in bones were clearly site related (Fig. 3). In modern bones, N/S ratios ranged from 35 to 120 (Table 1 ). Similar values of N/ $S$ ratios were found in bones from Hohle Fels, with a range of 30 to 128 (Table 1). In contrast, a large proportion of bones from Kesslerloch exhibited lower N/S ratios, ranging from 5 to 97 (Table 1) and even less for bones from Noyen-sur-Seine, which ranged from 3 to 39 (Table 1). This reflects a higher sulphur contamination level in bones from the river bank site Noyen-sur-Seine than in bones from the cave sites Kesslerloch and Hohle Fels.

\subsection{Chemical composition of collagen}

The chemical characteristics of collagen with respect to sulphur, i.e. \%S, C/S and $\mathrm{N} / \mathrm{S}$, are different in modern and archaeological bones (Table 2). Collagen extracted from modern mammal bones yielded \%S ranging from $0.14 \%$ to $0.33 \%, \mathrm{C} / \mathrm{S}$ ranging from 345 to 873 and N/S ranging from 103 to 266. Caribou, camel and bear bones had different sulphur amounts, with \%S ranging from $0.23 \%$ to $0.33 \%$ in caribou and \%S ranging from $0.17 \%$ to $0.19 \%$ in camel and from $0.14 \%$ to $0.19 \%$ in bears (Table 2 in supplementary data). The collagen extracted from the Greek turtle did not differ from that of the studied mammals (Table 2). In collagen extracted from bones from Noyen-sur-Seine, $\%$ ranged from $0.13 \%$ to $0.26 \%$ and from $0.22 \%$ to $0.45 \%$ in mammals and reptiles (European pond turtles), respectively; C/S ranged from 424 to 871 and from 235 to 491 in mammals and reptiles, respectively; N/S ranged from 130 to 274 and from 73 to 153 in mammals and reptiles, respectively (Table 3 in supplementary data). A systematic contrast in collagen composition was thus observed between mammals and reptiles from Noyen-surSeine.

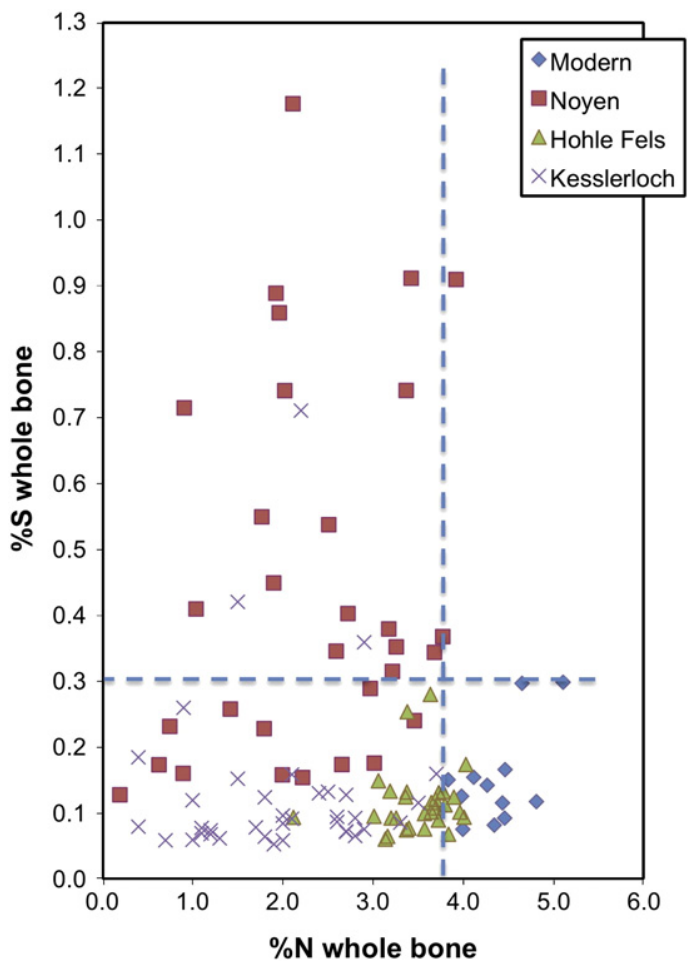

Fig. 2. Relationship between sulphur amount in whole bone (\%S whole bone) and nitrogen amount in whole bone (\%N whole bone) for modern bones and archaeological bones from Noyen-sur-Seine, Hohle Fels and Kesslerloch. The vertical dotted line represents the lowest level of nitrogen in modern bone, while the horizontal dotted line represents the highest level of sulphur in modern bone.

\subsection{Sulphur isotopic composition of bone and collagen}

The $\delta^{34} \mathrm{~S}$ values were measured for whole bone sulphur and for collagen extracted from archaeological bones from Noyen-sur-Seine (Table 3 in supplementary data). The $\delta^{34} \mathrm{~S}$ values ranged from -32.3 to\% $-13.0 \%$ in bone (Table 3 in supplementary data) while they ranged from $-29.1 \%$ o to $4.6 \%$ in collagen. Large variations were observed in bone collagen between different specimens of a given species, for instance a range from $-14.8 \%$ o to $0.1 \%$ for red deer and from $-11.4 \%$ o to $4.6 \%$ in roe deer. The most negative $\delta^{34} \mathrm{~S}$ values were, nonetheless, measured in specimens from freshwater species, such as otter and European pond turtle (Table 3 in supplementary data).

\section{Discussion}

As predicted from the deposit context, the archaeological bones from the three archaeological sites differ in the amount of sulphur that they contain. The bones from Noyen-sur-Seine, a site located in the valley of a large river, contain large amounts of contaminating sulphur. Between the two caves, the bones from Kesslerloch, a site

Table 1

Summary of the chemical composition (\%N, \%S, N/S) of modern and archaeological bones.

\begin{tabular}{|c|c|c|c|c|c|c|c|c|c|c|c|c|c|c|}
\hline \multirow[t]{2}{*}{ Material } & \multirow[t]{2}{*}{ Taxa } & \multirow[t]{2}{*}{$\mathrm{n}$} & \multicolumn{4}{|l|}{$\% \mathrm{Nb}$} & \multicolumn{4}{|l|}{$\% \mathrm{Sb}$} & \multicolumn{4}{|c|}{$\mathrm{N} / \mathrm{S}_{\text {atom }}$} \\
\hline & & & av & sd & $\min$ & $\max$ & av & sd & $\min$ & $\max$ & av & sd & $\min$ & $\max$ \\
\hline Modern & Mammals & 11 & 4.36 & 0.37 & 3.83 & 5.1 & 0.15 & 0.07 & 0.08 & 0.3 & 78.56 & 28.63 & 35.73 & 120.47 \\
\hline Modern & Reptiles & 1 & 4.46 & & & & 0.17 & & & & 61.23 & & & \\
\hline Hohle Fels & Mammals & 29 & 3.49 & 0.39 & 2.12 & 4.03 & 0.12 & 0.05 & 0.06 & 0.28 & 76.55 & 23.79 & 26.9 & 127.91 \\
\hline Kesslerloch & Mammals & 40 & 1.95 & 0.85 & 0.4 & 3.7 & 0.13 & 0.12 & 0.05 & 0.71 & 47.58 & 25.5 & 4.94 & 97.11 \\
\hline Noyen-sur-Seine & Mammals & 27 & 2.32 & 1.07 & 0.19 & 3.92 & 0.39 & 0.24 & 0.13 & 0.91 & 16.94 & 10.2 & 2.9 & 39.04 \\
\hline Noyen-sur-Seine & Reptiles & 4 & 2.14 & 0.22 & 1.92 & 0.22 & 0.84 & 0.23 & 0.54 & 1.18 & 6.48 & 2.52 & 4.1 & 10.66 \\
\hline
\end{tabular}




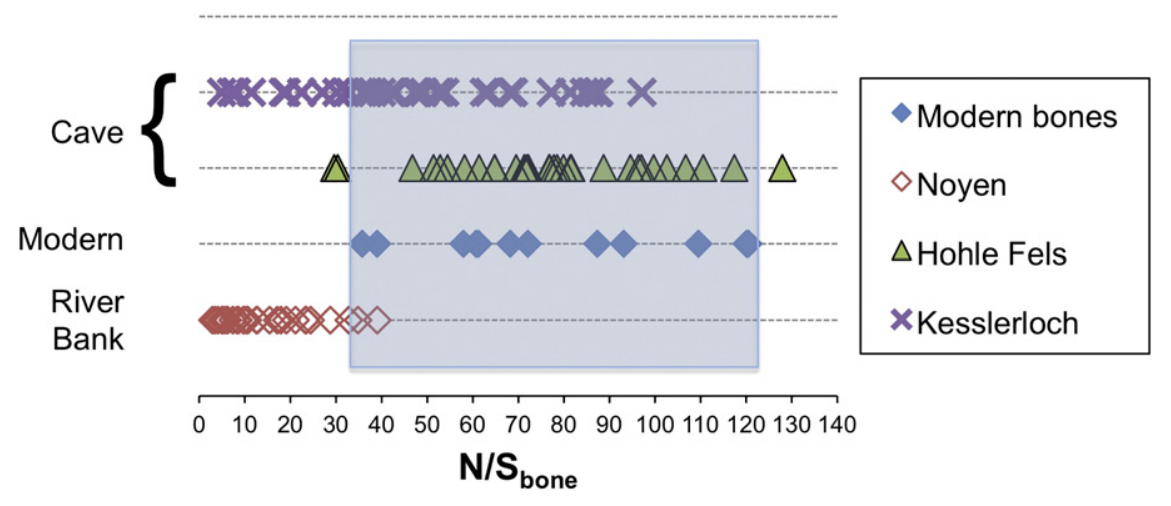

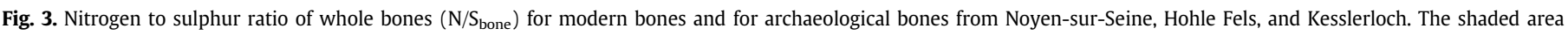
represents the range of $\mathrm{N} / \mathrm{S}$ in modern bones.

located at the level of the valley, contained higher amounts of sulphur than those from Hohle Fels, a site for which the entrance is located several meters above the valley floor. In Hohle Fels, the bones were well preserved, with high nitrogen content and low sulphur content similar to those of fresh bones, suggesting limited loss of collagen and small amount of contaminating sulphur. The preservation of collagen in bones from Hohle Fehls was confirmed by the high extraction yields and the chemical composition of collagen extracted from these samples that is identical to that of collagen from fresh bones that were obtained during a study of the palaeodiet of late Pleistocene lions and coeval large mammals (Bocherens et al., in press).

The range of \% measured on modern mammal bone collagen in the present study is similar to that obtained by Nehlich and Richards (2009) for mammal collagen from fresh bone: 0.14 to $0.33 \% \mathrm{~S}$ and 0.15 to $0.35 \% \mathrm{~S}$, respectively (Table 2 ). The range of $\mathrm{C} / \mathrm{S}$ and $\mathrm{N} / \mathrm{S}$ in modern collagen is also similar to those in this study and the study of Nehlich and Richards (2009): the C/S has a range from 300 to 900 in Nehlich and Richards (2009) and from 345 and 873 in the present study, while the N/S ranged from 100 and 300 in Nehlich and Richards (2009) and from 103 to 266 for the present study. The larger range measured by Nehlich and Richards (2009) may be a consequence of the larger dataset. Although the modern collagen samples were treated and measured independently in both studies, they had a similar chemical composition. The difference in sulphur amount observed between caribou collagen and bear and camel collagen may be due to animalspecific differences, although no clear difference in the amount of sulphur in mammal collagen was detected by Nehlich and Richards (2009). An alternative explanation for the difference in \%S between the modern collagen could have been the different flesh removing process. Indeed, the caribou bones from Banks Island were collected in the field already defleshed, but exposed to low temperatures only. In contrast, the bear bones from Alberta were defleshed from fresh carcasses in a museum, possibly using either a heat or chemical treatment (e.g., Hoffmeister and Lee, 1963; Jakway et al., 1970; Ossian,
1970). This process could have modified the sulphur content of the bone collagen in a different way compared to the natural decay of flesh. However, the fact that defleshed bear bones collected in the field yielded collagen with similar \% compared to bear bones collected from the museum does not support this hypothesis. However, more systematic investigations on the impact of the process of defleshing on the amount of sulphur should be performed. We also recommend that more species-level studies of the amount of sulphur in collagen are to be done in order to compare sulphur contents in collagen from fossils or modern species in more detail.

In contrast to the suggestion from Nehlich and Richards (2009) that reptile collagen may contain more sulphur than mammal collagen, the amount of sulphur measured for collagen from the Greek turtle in this study is similar to that from mammal collagen. Therefore, the reference dataset for modern reptiles should also be increased at the species level, and this may also be necessary for other vertebrates, such as birds and amphibians.

In the collagen extracted from mammal bones from Noyen-surSeine, the range of sulphur content was within the range of sulphur content for modern mammal collagen: 0.13 to $0.26 \%$ (Table 2). The European pond turtle, a reptile, exhibited higher \%S in collagen, ranging from 0.22 to $0.45 \%$ (Table 2 ). Since the only two reptile bones analysed for this parameter so far yielded very contrasted \%S, one of $0.19 \%$ (this study) and the other one of $0.9 \%$ (Nehlich and Richards, 2009), it is unclear whether such high sulphur amounts have been increased by contamination or reflect a biogenic high sulphur content of bone collagen for these reptiles. If the collagen $\mathrm{C} / \mathrm{S}$ and N/S ratios are used as an indicator for the reliability of sulphur isotope measurements, the mammal bone collagen from Noyen-sur-Seine has a range from 424 to 871 and from 130 to 274 for C/S and N/S, respectively. These ranges are within those obtained for modern mammal collagen by Nehlich and Richards (2009), and therefore the sulphur isotope measurements would likely indicate original, biogenic values too. Only some pond turtle bones have lower $\mathrm{C} / \mathrm{S}$ and $\mathrm{N} / \mathrm{S}$,

Table 2

Summary of the chemical composition (\%N, \%C, \%S, C/S, N/S) of modern and archaeological collagen. Modern data from Nehlich and Richards (2009) are given for comparison.

\begin{tabular}{|c|c|c|c|c|c|c|c|c|c|c|c|c|c|c|c|c|c|c|c|c|c|c|}
\hline \multirow[t]{2}{*}{ Material } & \multirow[t]{2}{*}{ Taxa } & \multirow[t]{2}{*}{$\mathrm{n}$} & \multicolumn{4}{|l|}{$\% \mathrm{~N}$} & \multicolumn{4}{|l|}{$\% \mathrm{C}$} & \multicolumn{4}{|l|}{$\% S$} & \multicolumn{4}{|l|}{$\mathrm{C} / \mathrm{S}$} & \multicolumn{4}{|l|}{$\mathrm{N} / \mathrm{S}$} \\
\hline & & & av & sd & $\min$ & $\max$ & $\mathrm{av}$ & sd & $\min$ & $\max$ & $\mathrm{av}$ & sd & $\min$ & $\max$ & $\mathrm{av}$ & sd & $\min$ & $\max$ & av & sd & $\min$ & $\max$ \\
\hline Modern (this study) & Mammals & 22 & 15.2 & 0.60 & 14.1 & 16.3 & 43.6 & 1.40 & 39.8 & 45.8 & 0.2 & 0.06 & 0.14 & 0.33 & 624.1 & 158.5 & 345 & 873 & 186.9 & 48.3 & 103 & 266 \\
\hline $\begin{array}{l}\text { Modern (Nehlich and } \\
\text { Richards, 2009) }\end{array}$ & Mammals & 41 & 16.15 & 0.51 & & & 44.41 & 0.86 & & & 0.28 & 0.07 & & & 600 & 300 & 300 & 900 & 200 & 100 & 100 & 300 \\
\hline Modern (this study) & Reptile & 1 & 15.1 & & & & 43.7 & & & & 0.19 & & & & 613.3 & & & & 181.7 & & & \\
\hline $\begin{array}{l}\text { Modern (Nehlich and } \\
\text { Richards, 2009) }\end{array}$ & Reptile & 1 & 15.32 & & & & 46.45 & & & & 0.91 & & & & 136 & & & & 38 & & & \\
\hline Kesslerloch & Mammals & 41 & 14.4 & 1.03 & 10.8 & 16.1 & 40.6 & 3.41 & 30.4 & 46.3 & 0.2 & 0.067 & 0.12 & 0.33 & 623.3 & 229.6 & 279 & 1029 & 188 & 65.45 & 95 & 307 \\
\hline Noyen-sur-Seine & Mammals & 28 & 15.2 & 0.39 & 14.2 & 15.8 & 41.7 & 0.76 & 39.7 & 42.8 & 0.2 & 0.03 & 0.13 & 0.26 & 586.9 & 110 & 424 & 871 & 183.3 & 35.1 & 130 & 274 \\
\hline Noyen-sur-Seine & Reptiles & 5 & 14.3 & 0.33 & 13.7 & 14.7 & 39.6 & 1.01 & 37.6 & 40.5 & 0.35 & 0.08 & 0.22 & 0.45 & 323.5 & 90.8 & 235 & 491 & 100.3 & 28.4 & 73 & 153 \\
\hline
\end{tabular}


but as mentioned previously, this may reflect a different chemical composition of reptilian collagen rather than diagenetic alteration.

If the criteria set out by Nehlich and Richards (2009) are followed, where modern collagen is used as a reference dataset, all mammal samples from Noyen-sur-Seine would have retained their $\delta^{34} S$ values for collagen through diagenesis. In the present study, the rich assemblage of well identified specimens offers the possibility to go one step further: it is possible to evaluate the possible variations of $\delta^{34} \mathrm{~S}$ values according to species or to ecological groups as well as the possible co-variations of indicators of diagenetic intensity and $\delta^{34} \mathrm{~S}$ values of bone collagen. In Noyen-sur-Seine, a trend between $\delta^{34} \mathrm{~S}$ values and N/S ratios in bone was observed, for all bones analysed but also within samples from single species such as red deer and aurochs (Fig. 4): the most negative $\delta^{34} \mathrm{~S}$ values were measured on collagen extracted from bones that had the highest collagen loss and hence are most likely to be influenced by extraneous sulphur contamination. This co-variation between very low $\delta^{34} \mathrm{~S}$ values in collagen and increasing diagenetic alteration can be extrapolated to determine the non-biogenic sulphur source for the contamination. When comparing the $\% \mathrm{~S}$ in collagen and the N/S ratio in bones, a co-variation between high \% in collagen and low N/S ratios in bones occurs in Noyen-surSeine (Fig. 5). This implies that the bones from Noyen-sur-Seine that experienced a higher collagen loss also yielded collagen with more \%S than other samples from the same sites, indicative of a new, contamination sulphur source. It is, therefore, conceivable that the bones that were most heavily contaminated with extraneous sulphur also contain collagen to which some contaminating sulphur has been added and hence its $\delta^{34} \mathrm{~S}$ values were changed, even if the \%S remained within the range observed for modern mammal collagen by Nehlich and Richards (2009). The $\delta^{34} \mathrm{~S}$ values measured on whole bone sulphur were systematically more negative than that measured on collagen of the same bone (Table 3 in supplementary data). This indicates that the contaminating sulphur has a very low $\delta^{34} S$ value and could account for the decreasing $\delta^{34} S$ of collagen with increasing sulphur content of collagen.

In order to screen out collagen potentially affected by diagenetic alteration, we chose to use an additional tracer of diagenesis: the sulphur yield, which corresponds to the amount of sulphur extracted from collagen relative to the total sulphur that was present in the bone. This index is calculated using the following formula: $\mathrm{S}$ yield $=$ $\left(\% \mathrm{~S}_{\text {coll }} \times\right.$ Yield $\left._{\text {coll }}(\%)\right) / \% \mathrm{~S}_{\text {bone. }}$ It integrates the amount of sulphur in collagen as well as the contaminating sulphur and allows a direct comparison with the range of $\delta^{34} \mathrm{~S}$ values measured in collagen from different individuals of a given species or ecological type. In Noyen-sur-Seine, the co-variation between $\delta^{34} S$ values and $S$ yield is very clear, for all bone samples analysed as well as within the sample population of any one species (Fig. 6). Although the values of the pond turtle amplify this trend, it is still visible when only mammal collagen is taken into account. In particular, the lowest $\delta^{34} S$ values are observed

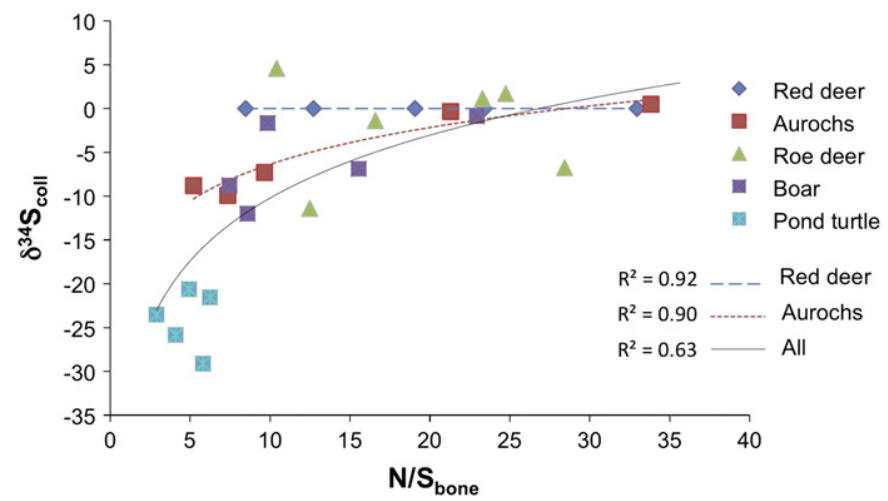

Fig. 4. Variation of $\delta^{34} \mathrm{~S}$ values in collagen $\left(\delta^{34} \mathrm{~S}_{\text {coll }}\right)$ according to $\mathrm{N} / \mathrm{S}_{\mathrm{bone}}$ in Noyen-sur-Seine.

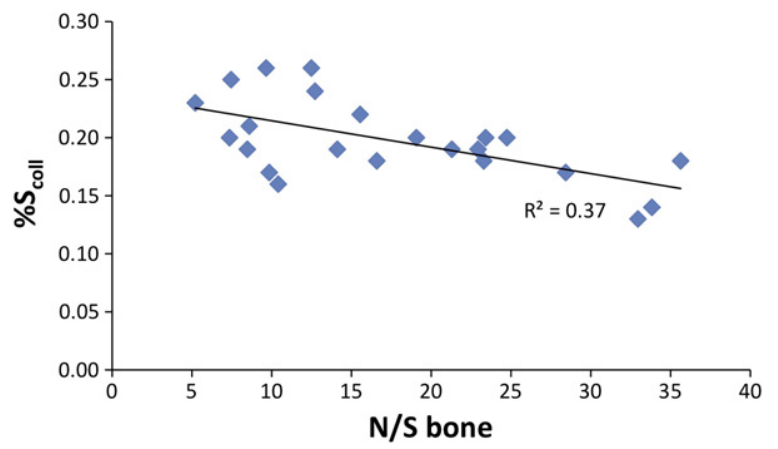

Fig. 5. Variation of the amount of sulphur in collagen $\left(\% \mathrm{~S}_{\text {coll }}\right)$ relative to $\mathrm{N} / \mathrm{S}$ in the whole bone in Noyen-sur-Seine.

for collagen with an S yield lower than $5 \%$ in the case of mammals, and $1.5 \%$ for turtles. These threshold values are approximate and subject to change with further studies of this kind. However, they are useful to detect samples with sulphur isotopic values that may have been affected by diagenetic alteration.

Excluding the bone collagen $\delta^{34} S$ values of samples with evidence for diagenetic alteration provides a clear ecological separation between freshwater and terrestrial species (Fig. 7). This is not the case when all the collagen samples with chemical compositions within the limits set by Nehlich and Richards (2009) are used. The samples with $\delta^{34} \mathrm{~S}$ values ranging from $-13 \%$ and $-5 \%$ measured for specimens of terrestrial species are likely to be altered, since they correspond to specimens with low $\mathrm{S}$ yield and high levels of whole bone sulphur contamination. Finally, collagen of terrestrial mammals that has no evidence of diagenetic alteration also has higher $\delta^{34} \mathrm{~S}$ values compared to those of freshwater turtle and otter.

\section{Conclusions}

The present study indicates that in the Mesolithic site of Noyensur-Seine the $\delta^{34} \mathrm{~S}$ values of collagen that has a chemical composition within the range of modern collagen may not be excluded from the effects of diagenesis and hence that the collagen does not reflect the biogenic compositions any longer. These samples were contaminated with exogenous sulphur with a sulphur isotopic composition very different from that of the original bone collagen. This possibility may be common in fluvial and lacustrine contexts where reduced sources of sulphur may be present. Comparing the chemical composition (\%C, $\% \mathrm{~N}, \% \mathrm{~S}, \mathrm{C} / \mathrm{S}, \mathrm{N} / \mathrm{S}$ ) in ancient collagen with that of modern collagen may not be sufficiently precise to detect whether or not a sulphur contamination has occurred. However, there are some ways to test

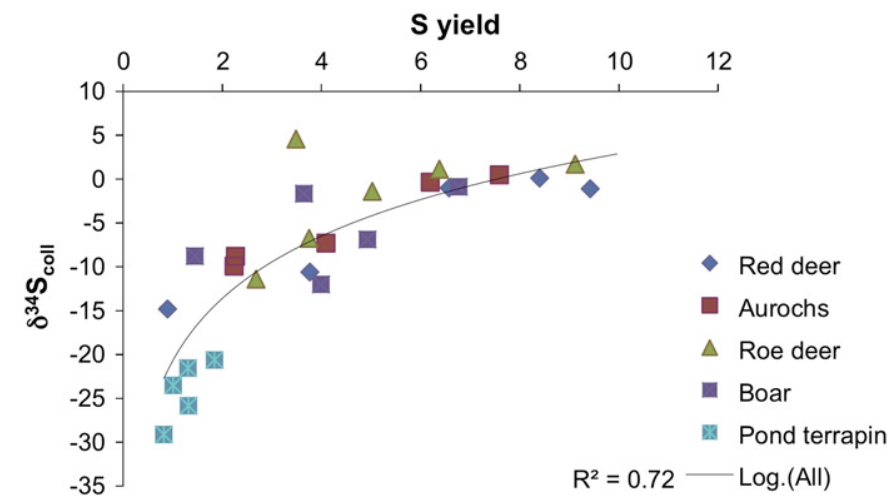

Fig. 6. Variation of $\delta^{34} S$ values in collagen $\left(\delta^{34} S_{\text {coll }}\right)$ relative to $S$ yield in Noyen-sur-Seine 


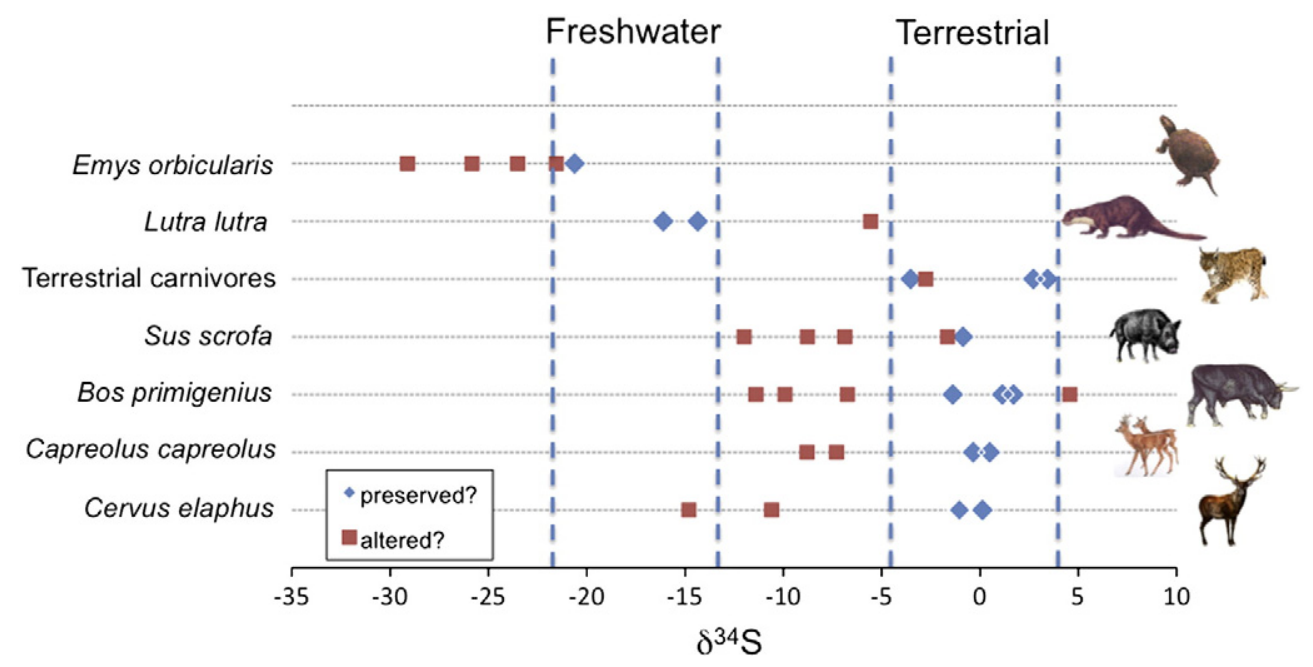

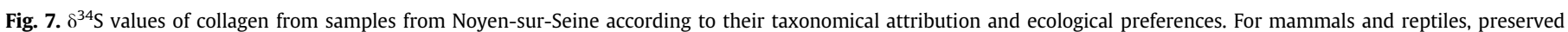
collagen are those with $\% \mathrm{~S}_{\text {coll }}<0.23$ and $\mathrm{S}$ yield $>5$, and $\% \mathrm{~S}_{\text {coll }}<0.35$ and $\mathrm{S}$ yield $>1.5$, respectively.

for such post-mortem isotopic alteration, using combined data from whole bones and the collagen chemical composition in conjunction with the sulphur isotopic composition of collagen. It is recommended to investigate possible co-variations of $\delta^{34} S$ values within species or ecological groups with proxies for diagenetic intensity such as \%S or $\mathrm{N} / \mathrm{S}$ in whole bones, \%S in collagen, and S yield in order to evaluate the influence of diagenesis. This approach should establish an empirical threshold for the reliability of collagen $\delta^{34} \mathrm{~S}$ values. Such threshold values may be site-related rather than of general use. Further research will be necessary to establish whether the pattern observed in the present study, i.e. bones from caves high above the valley floor being less contaminated with extraneous sulphur compared to bones from caves close to the valley bottom and themselves less contaminated than bones found in the river bed, is a general phenomenon in archaeological sites. We also suggest to study the variations of sulphur amounts in collagen from different tetrapod species further, as this may provide a more precise way to define acceptable values for the taxa studied in archaeological and palaeontological sites, including non-mammalian taxa that were important for prehistoric subsistence.

\section{Acknowledgements}

Thanks are due to A. Bridault, J.A. Burns, N.J. Conard, M. Höneisen, H. Müller-Beck, S.C. Münzel, H. Napierala, and H.-P. Uerpmann for providing bone samples, and to F. Baumann, D. Billiou, P. Kühn, A. Orendi, B. Steinhilber, and C. Wissing for technical assistance. We acknowledge the financial support provided by the PCR "Paléolithique final et Mésolithique dans le Bassin Parisien et ses marges" (dir. B. Valentin) and the Alexander von Humboldt Foundation. We are grateful to the editor and to the three anonymous reviewers for their suggestions that helped to improve the manuscript.

\section{Appendix A. Supplementary data}

Supplementary data to this article can be found online at doi:10.1016/j.palaeo.2011.05.016.

\section{References}

Athfield, N.B., Green, R.C., Craig, J., McFadgen, B., Bickler, S., 2008. Influence of marine sources on ${ }^{14} \mathrm{C}$ ages: isotopic data from Watom Island, Papua New Guinea inhumations and pig teeth in light of new dietary standards. J. Royal Soc. New Zealand 38, 1-23.
Bocherens, H., 2009. Possible freshwater resource consumption by the earliest directly dated European modern humans: implications for direct radiometric dating. PNAS 106 (41). doi:10.1073/pnas.0909392106.

Bocherens, H., Tresset, A., Wiedemann, F., Giligny, F., Lafage, F., Lanchon, Y., Mariotti, A., 1997a. Bone diagenetic evolution in two French Neolithic sites. Bull. Soc. Geol. Fr. $168,555-564$

Bocherens, H., Billiou, D., Patou-Mathis, M., Bonjean, D., Otte, M., Mariotti, A., 1997b. Paleobiological implications of the isotopic signatures $\left({ }^{13} \mathrm{C},{ }^{15} \mathrm{~N}\right)$ of fossil mammal collagen in Scladina Cave (Sclayn, Belgium). Quat. Res. 48, 370-380.

Bocherens, H., Billiou, D., Charpentier, V., Mashkour, M., 2000a. Palaeoenvironmental and archaeological implications of bone and tooth isotopic biogeochemistry $\left({ }^{13} \mathrm{C}\right.$, ${ }^{15} \mathrm{~N}$ ) in Southwestern Asia. In: Buitenhuis, H., Mashkour, M., Poplin, F. (Eds.), Archaeozoology of the Near East IV: Groningen: ARC 32, vol. B, pp. 104-115.

Bocherens, H., Tresset, A., Bridault, A., Vigne, J.-D., Chambon, P., Giligny, F., 2000b. Modes d'exploitation des ressources animales par des populations mésolithiques et néolithiques du Bassin Parisien: implications de l'archéozoologie et de la biogéochimie des restes osseux. XXVe Congrès Préhistorique de France "Approches fonctionnelles en Préhistoire", Programme et Résumé des Communications. Société Préhistorique française, pp. 84-86.

Bocherens, H., Drucker, D., Billiou, D., Moussa, I., 2005. Une nouvelle approche pour évaluer l'état de conservation de l'os et du collagène pour les mesures isotopiques (datation au radiocarbone, isotopes stables du carbone et de l'azote). l'Anthropologie 109, 557-567.

Bocherens, H., Drucker, D.G., Billiou, D., Geneste, J.-M., Kervazo, B., 2008. Grotte Chauvet (Ardèche, France): a "natural experiment" for bone diagenesis in karstic context. Palaeogeogr. Palaeoclimatol. Palaeoecol. 266, 220-226.

Bocherens, H., Drucker, D.G., Bonjean, D., Bridault, A., Conard, N.J., Cupillard, C., Germonpré, M., Höneisen, M., Münzel, S.C., Napierrala, H., Patou-Mathis, M., Stephan, E., Uerpmann, H.-P., Ziegler, R. in press. Isotopic evidence for dietary ecology of cave lion (Panthera spelaea) in North-western Europe: prey choice, competition and implications for extinction. Quat. Int. DOI:10.1016/j.quaint.2011.02.023.

Bösl, C., Grupe, G., Peters, J., 2006. A Late Neolithic vertebrate food web based on stable isotope analyses. Int. J. Osteoarchaeol. 16, 296-315.

Cheylan, M., 1998. Evolution of the distribution of the European pond turtle in the French Mediterranean area since the post-glacial. In: Fritz, U., Joger, U., Podloucky, R., Servan, J. (Eds.), Proceedings of the EMYS Symposium Dresden 96: Mertensiella, 10, pp. 47-65.

Chiquet, P.A., Chaix, L., 2009. La faune du Néolithique ancien. In: Voruz, Jean-Louis (Ed.), La grotte du gardon (Ain). : le site et la séquence néolithique des couches 60 à 47, volume 1. Ecole des hautes études en sciences sociales, Toulouse, pp. 397-450.

Cook, G.T., Bonsall, C., Hedges, R.E.M., McSweeney, K., Boronean, V., Pettitt, P.B., 2001. A freshwater diet-derived ${ }^{14} \mathrm{C}$ reservoir effect at the Stone Age sites in the iron Gates Gorge. Radiocarbon 43, 453-460.

Craig, O.E., Ross, R., Andersen, S.H., Milner, N., Bailey, G.N., 2006. Sulphur isotope variation in archaeological marine fauna from northern Europe. J. Archaeol. Sci. 33, 1642-1646.

Craig, O.E., Biazzo, M., Colonese, A.C., Di Giuseppe, Z., Martinez-Labarga, C., Lo Vetro, D., Lelli, R., Martini, F., Rickards, O., 2010. Stable isotope analysis of Late Upper Palaeolithic human and faunal remains from Grotta del Romito (Cosenza). Italy. J. Archaeol. Sci. 37, 2504-2512.

Drucker, D.G., Bocherens, H., 2004. Carbon and nitrogen stable isotopes as tracers of diet breadth evolution during Middle and Upper Palaeolithic in Europe. Int. J. Osteoarchaeol. 14, 162-177.

Drucker, D.G., Bocherens, H., Billiou, D., 2003. Evidence for shifting environmental conditions in Southwestern France from 33,000 to 15,000 years ago derived from carbon-13 and nitrogen-15 natural abundances in collagen of large herbivores. Earth Planet. Sci. Lett. 216, 163-173. 
Dufour, E., Bocherens, H., Mariotti, A., 1999. Palaeodietary implications of isotopic variability in Eurasian lacustrine fish. J. Archaeol. Sci. 26, 627-637.

Gramsch, B., Larsson, L., 2001. Zwei ornamentierte Rückenpanzer der Sumpfschildkröte aus dem Mesolithikum des zirkumbaltischen Raumes. In: Gehlen, B., Heinen, M. Tillmann, A. (Eds.), Zeit-Räume: Gedenkschrift für Wolfgang Taute: Archäologische Berichte, 14, pp. 455-464.

Hoffmeister, D.F., Lee, M.R., 1963. Cleaning mammalian skulls with ammonia hydroxide. J. Mammalogy 44, 283-284.

Iacumin, P., Bocherens, H., Mariotti, A., Longinelli, A., 1996. An isotopic palaeoenvironmental study of human skeletal remains from the Nile Valley. Palaeogeogr. Palaeoclimatol. Palaeoecol. 126, 15-30.

Jakway, G.E., Raskin, W., Thyle, T., 1970. Sodium perborate process for preparation of skeletons. Turtox News 48, 65-67.

Kerkesz, R., 2002. Mesolithic hunter-gatherers in the northwestern part of the Great Hungarian Plain. Praehistoria 3, 281-304.

Krouse, H.R., 1989. Sulfur isotope studies of the pedosphere and biosphere. In: Rundel, P.W., Ehleringer, J.R., Nagy, K.A. (Eds.), Stable Isotopes in Ecological Research. Springer-Verlag, NY, pp. 424-444.

Leach, B.F., Quinn, C.J., Lyon, G.L., 1996. A stochastic approach to the reconstruction of prehistoric human diet in the Pacific region from bone isotope signatures. Tahingu: Records of the Museum of New Zealand Te Papa Tongarewa 8, 1-54.

Lehmkuhl, U., 1989. Meso- und neolithische Funde der Europäischen Sumpfschildkröte (Emys orbicularis L.) im Norden der DDR. Ausgrabungen und Funde 34, 107-112.

Lillie, M., Richards, M.P., Jacobs, K., 2003. Stable isotope analysis of 21 individuals from the Epipalaeolithic cemetery of Vasilyevka III, Dnieper Rapids region, Ukraine. J. Archaeol. Sci. 30, 743-752.

Longin, R., 1971. New method of collagen extraction for radiocarbon dating. Nature 230, 241-242.

Marinval-Vigne, M.-C., Mordant, D., Auboire, G., Augereau, A., Bailon, S., Dauphin, C. Delibrias, G., Krier, V., Leclerc, A.-S., Leroyer, C., Marinval, P., Mordant, C., Rodriguez, P., Vilette, P., Vigne, J.D., 1989. Noyen-sur-Seine, site stratifié en milieu fluviatile: une étude multidisciplinaire intégrée. Bull. Soc. Préhist. Fr. 86, 370-379.
Merk, C., 1876. Excavations at the Kesslerloch near Thaygen, Switzerland. Longmans, Green and Co, London. 65 pp.

Münzel, S.C., Hofreiter, M., Stiller, M., Conard, N.J., Bocherens, H., 2008. Neue Ergebnisse zur Paläobiologie der Höhlenbären auf der Schwäbischen Alb (Chronologie, Isotopie und Paläogenetik). Stalactite 58, 27-30.

Napierala, H., 2008. Die Tierknochen aus dem Kesslerloch. Neubearbeitung der paläolithischen Fauna. Beiträge zur Schaffhauser Archäologie, pp. 1-128.

Nehlich, O., Richards, M.P., 2009. Establishing collagen quality criteria for sulphur isotope analysis of archaeological bone collagen. Archaeol. Anthropol. Sci. 1, 59-75.

Nehlich, O., Borić, D., Stefanovic, S., Richards, M.P., 2010. Sulphur isotope evidence for freshwater fish consumption: a case study from the Danube Gorges, SE Europe. J. Archaeol. Sci. 37, 1131-1139.

Olsen, J., Heinemeier, F., Lübke, H., Lüth, F., Terberger, T., 2010. Dietary habits and freshwater reservoir effects in bones from a Neolithic NE German cemetery. Radiocarbon 52, 635-644.

Ossian, C.R., 1970. Preparation of disarticulated skeletons using enzyme-based laundry presoakers. Copeia 1970, 199-200.

Privat, K.L., O'Connell, T.C., Hedges, R.E.M., 2007. The distinction between freshwaterand terrestrial-based diets: methodological concerns and archaeological applications of sulphur stable isotope analysis. J. Archaeol. Sci. 34, 1197-1204.

Richards, M.P., Fuller, B.T., Hedges, R.E.M., 2001. Sulphur isotopic variation in ancient bone collagen from Europe: implications for human palaeodiet, residence mobility, and modern pollutant studies. Earth Planet. Sci. Lett. 191, 185-190.

Richards, M.P., Fuller, B.T., Sponheimer, M., Robinson, T., Ayliffe, L., 2003. Sulphur isotopes in palaeodietary studies: a review and results from a controlled feeding experiment. Int. J. Osteoarchaeol. 13, 37-45.

Schiegl, S., Goldberg, P., Pfretzschner, H.-U., Conard, N.J., 2003. Paleolithic burnt bone horizons from the Swabian Jura: distinguishing between in situ fireplaces and dumping areas. Geoarchaeology 18, 541-565.

Sommer, R.S., Persson, A., Wieseke, N., Fritz, U., 2007. Holocene recolonization and extinction of the pond turtle Emys orbicularis (L., 1758), in Europe. Quat. Sci. Rev. 26, 3099-3107. 